\title{
COMPRESSIVE STRENGTH BEHAVIOURS OF LAGOON- WATER CURED CEMENT-ALUMINIUM DROSS CONCRETE
}

Olusegun A. Afolabi ${ }^{1, *}$, Atinuke Oladoye ${ }^{2}$, Obanishola M. Sadiq ${ }^{3}$, and Samson O. Adeosun $^{4}$

${ }^{1}$ Department of Civil and Environmental Engineering, University of Lagos, Nigeria. Emails: oafolabi@unilag.edu.ng

${ }^{2}$ Department of Metallurgical and Materials Engineering, University of Lagos, Nigeria. Emails: aoladoye@unilag.edu.ng

${ }^{3}$ Department of Civil and Environmental Engineering, University of Lagos, Nigeria. Emails: osadiq@unilag.edu.ng

${ }^{4}$ Department of Metallurgical and Materials Engineering, University of Lagos, Nigeria. Email: sadeosun@unilag.edu.ng

* Corresponding author

https://doi.org/10.30572/2018/kje/120405

\begin{abstract}
This study investigates the compressive strengths of concrete cubes and reinforced columns cast with partial replacement of cement using 0- $25 \mathrm{wt}$ \% Aluminum dross (AlDr) and cured in Lagoon water for 7-42days and 1-6 months respectively. The results indicated cubes with 5 wt.\% AlDr, 10 wt. \% AlDr and control possess strength of $15 \mathrm{~N} / \mathrm{mm}^{2}, 14.59 \mathrm{~N} / \mathrm{mm}^{2}$ and $13.48 \mathrm{~N} / \mathrm{mm}^{2}$ respectively at 28 -day curing while at 42 -day the results are $16.89 \mathrm{~N} / \mathrm{mm}^{2}$, $12.22 \mathrm{~N} / \mathrm{mm}^{2}$ and $16.96 \mathrm{~N} / \mathrm{mm}^{2}$ for control, 5 and $10 \mathrm{wt} \%$ AlDr respectively. The 42-day compressive strength $(79.48 \%)$ confirmed the performance at 28-day strength (75\%). Control cube (74.6-95.5\%) has higher crystallinity compared to cement (65.1-90.1\%) and AlDr (62.4$74.0 \%$ ) but at $15 \mathrm{wt} . \%$ AlDr concrete the crystallinity (78.1-96.2\%) is superior with marginal crystal sizes variation (12.8-16.9 $)$. The strength $\left(\sim 9.5 \mathrm{~N} / \mathrm{mm}^{2}\right)$ with 10 wt. \% AlDr column cured for 6 months was better than the control columns environment $\left(\sim 7 \mathrm{~N} / \mathrm{mm}^{2}\right)$ at 2-month.
\end{abstract}

KEYWORDS: Aluminum dross, Cement, Lagoon water cured, Compressive strengths, Crystal sizes, Column 


\section{INTRODUCTION}

The world cement production is over 4 billion tons and this accounts for the third largest source of carbon dioxide after fossil fuels and land -use changes respectively. This contributes to greenhouse effects and acid rain with emission of $\mathrm{SO}_{2}, \mathrm{NOx}$ (Nitrous Oxide) (Valipour, 2014). The $\mathrm{CO}_{2}$ emission from cement production is estimated at $1.45 \pm 0.20 \mathrm{Gt}$ (Giga tonne) for the year 2016 (Andrew, 2018). The cement industry is thus faced with tremendous challenges to address these issues. In the light of this, studies are ongoing on partial replacement of cement by utilization of by-products/ wastes like fly ash, AlDr, slag, silica fume, rice husk ash etc., which are termed supplementary cementitious materials (SCM). Studies are on the increase to reduce cement consumption in the construction and building industries owing to the volume of hazardous effluents that are produced during cement production that destroy the ecosystem and impact negatively the climate change and its attendant world problems. The use of AlDr as partial replacement for cement is a cost reduction mechanism as it does not entail refining and prevents open dumping of this environmentally unfriendly waste. Earlier Galat et al., (2017) observed the compressive strength of cubes cured for 28 days increased with addition of $10 \mathrm{wt}$. $\%$ AlDr. Reddy and Neeraja (2016) replaced cement partially with secondary aluminium dross and found that compressive strength responses are comparable with the conventional concrete up to $15 \mathrm{wt}$ \% AlDr. On the other hand, the use of concrete takes place both on land and in marine environment. The degradation rate of concrete depends on a lot of factors one of which is the service environment. In marine environment, the diffusion of chloride ions, present in deicing salts, lagoon and seawater in the presence of oxygen and moisture can cause deterioration of concrete and steel reinforced concrete structures. Cracks in concretes are the paths for Chlorides transport into the concrete matrix resulting into corrosion. Chlorides initiate corrosion while the rate-controlling factors are availability of oxygen, the electrical resistivity and relative humidity of the concrete, and the $\mathrm{pH}$ and temperature. Higher chloride ion contents above a threshold, breaks the passivation film with attendant pitting corrosion. Pitting corrosion occur rapidly and noxiously to prevent the formation of a passivation layer over concrete surface (Neville, 1995; Abbas et al., 2014). Structures close to sea and lagoon water areas like bridges and buildings whether residential or commercial /institutional like University of Lagos, Nigeria location are prone to pitting corrosion.

\section{METHODOLOGY}

The experimental test and observations, were performed according to "BS 1881-Testing Concrete". This involves determination of the setting times for cement - aluminum dross paste 
and compressive strength for cement-aluminum dross concrete cubes and cement-aluminum dross reinforced columns. Specimen paste was prepared and tested according to BS EN 1963:2005 using cement mortar/ 400g of Dangote brand of cement $(42.5 \mathrm{~N})$ and mixed with $120 \mathrm{ml}$ of water for $\sim 3$ mins. The chemical properties of lagoon and laboratory water used for curing are shown in Tables 1 and 2 respectively. The $\mathrm{pH}$ and salinity of lagoon waters were determined using HANNA HI 9813-6 model meter and MP 521 Meter respectively. The Chloride ion presence was obtained via the Mohr's method, using silver nitrate and potassium chloride as indicator. Acidity of the water solution was obtained via Acid-base titration using hydrochloric acid as titrant and phenolphatalin as indicator while alkalinity value obtained via Acid-base titration, using sodium hydroxide as titrant and methyl orange as indicator.

Table 1. Properties of lagoon water used for cube immersion.

\begin{tabular}{cccccc}
\hline Day & $\mathrm{pH}$ & $\begin{array}{c}\text { Acidity } \\
(\mathrm{mg} / \mathrm{l})\end{array}$ & $\begin{array}{c}\text { Alkalinity } \\
(\mathrm{mg} / \mathrm{l})\end{array}$ & $\begin{array}{c}\text { Salinity } \\
(\mathrm{ppm})\end{array}$ & $\begin{array}{c}\text { Chloride ion, } \\
(\mathrm{mg} / \mathrm{l})\end{array}$ \\
\hline 7 & 6.3 & 8 & 110 & 110 & 8 \\
14 & 6.3 & 12 & 84 & 110 & 88 \\
21 & 6.6 & 12 & 100 & 120 & 88 \\
28 & 6.0 & 12 & 80 & 120 & 92 \\
42 & 6.6 & 44 & 140 & 1208 & 1120 \\
Standard & & $\mathrm{pH} \geq 6.0$, Salinity=1000 ppm, Chloride ion= 500 mg/l, \\
& & \multicolumn{4}{c}{ acidity=500mg/l, alkalinity=500mg/l } \\
\hline
\end{tabular}

Table 2. Properties of Lagoon water used for reinforced curing column.

\begin{tabular}{ccc}
\hline S/No & Test Parameters & $\begin{array}{c}\text { Specimen A } \\
\text { (Water sample) }\end{array}$ \\
\hline 1 & $\mathrm{pH}$ & 6.16 \\
2 & Conductivity & 22600 \\
& $(\mu \mathrm{S} / \mathrm{cm})$ & \\
3 & TDS $(\mathrm{ppm})$ & 20900 \\
4 & Salinity $(\mathrm{ppm})$ & 19000 \\
5 & Chloride ion $(\mathrm{mg} / \mathrm{l})$ & 18000 \\
6 & Acidity $(\mathrm{mg} / \mathrm{l})$ & 40 \\
7 & Alkalinity $(\mathrm{mg} / \mathrm{l})$ & 92 \\
8 & Temperature & $29.6\left({ }^{\circ} \mathrm{C}\right)$ \\
\hline
\end{tabular}




\subsection{Preparation and curing of concrete cubes}

The concrete mixture was prepared using constituent mix ratio of 1:2:4 (Cement/AlDr: Fine: Coarse aggregate) by weight, and the AlDr replacement levels were $0-25$ wt. $\%$ of cement. The water/cement ratio is $0.45: 1$. The aggregates are normal size with fine aggregates passing through the $4.76 \mathrm{~mm}$ diameter sieve while the coarse aggregates are within $5-16 \mathrm{~mm}$ sieve size. Total number of $150 \times 150 \times 150 \mathrm{~mm}$ concrete cubes cast for tests $=90$ with 3 cubes per test. The concrete cubes were cured by immersion in the lagoon water for 7-42 days. Before compression test was done the weight measurement of dried cured cast concrete cubes was conducted three times to ascertain accuracy and the mean value recorded using Universal Weight Electronic Machine (Maximum load = 8kg; d= 0.1g) before compression test (Fig. 4). Thereafter, Concrete compressive test was performed in the laboratory using the universal testing machine where the load is gradually applied unto a concrete specimen till failure/fracture.

\subsection{Casting of Columns}

The Concrete constituent materials were measured and proportioned according to design mix of 1:2:4 (cement: sand: crashed stone) and batched into the mixer for production of fresh concrete to cast the $150 \times 150 \times 1000 \mathrm{~mm}$ nominally reinforced concrete columns. According to design codes specification, minimum reinforcement must be provided as follows, $100 \mathrm{~A} / \mathrm{bh}$ $>0.4$ or $\mathrm{A}_{\mathrm{s}}>90 \mathrm{~mm}^{2}\left(\mathrm{~A}_{\mathrm{s}}\right.$ is cross-sectional area of steel bar, bh - cross sectional area of the concrete column). Four $8 \mathrm{~mm}$ diameter and $950 \mathrm{~mm}$ long $\left(\mathrm{F}_{\mathrm{y}}=410 \mathrm{~N} / \mathrm{mm}^{2}\right.$, High yield) bar was used as longitudinal reinforcement with $\mathrm{A}_{\mathrm{s}}=201 \mathrm{~mm}^{2}$; and for the shear links similar bar diameter were used at $237.5 \mathrm{~mm}$ spacing. A total of 150 column specimens (see Fig. 1) were cast and cured in Lagoon water for 1, 1.5, 2, 2.5 and 6 months with 2 columns tested for compression failure by per weight percent AlDr replacement of cement and the average results taken as representative of the two columns. 


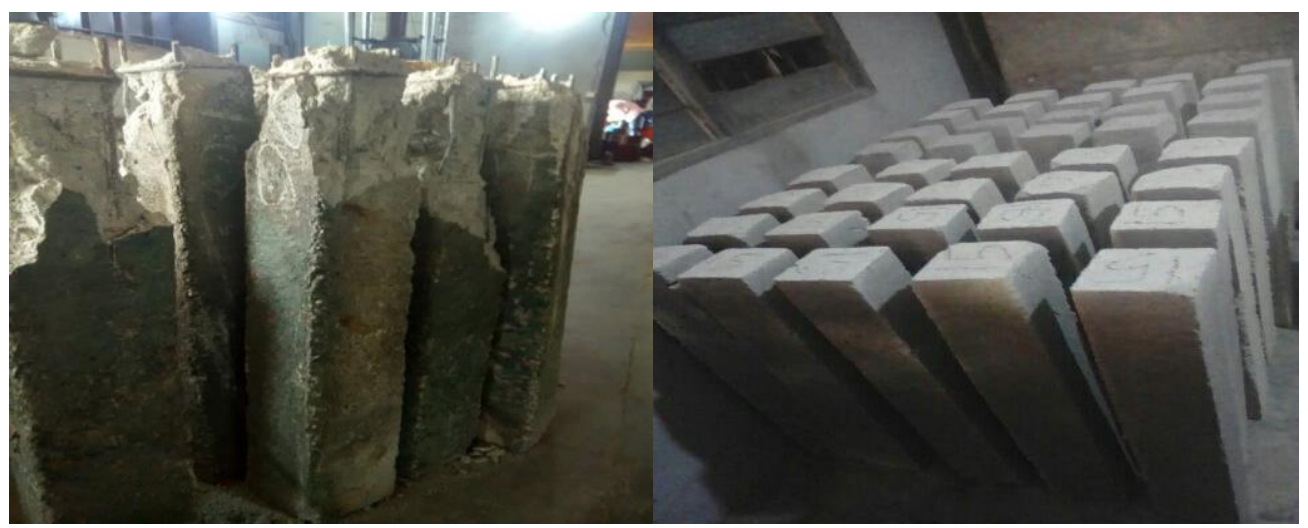

b

a

Fig. 1. (a) Cast concrete column (b) compression to failure concrete column.

\subsection{X-Ray Diffraction (XRD)}

The XRD was carried out using PANanalytical Empyrean situated at National Geosciences Research Laboratories, Nigeria Survey Agency (Kaduna, Nigeria). This characterization was done to determine phases formed during the curing process, the crystal sizes and crystallinity index. Samples were exposed to a monochromatic $\mathrm{Cu} \mathrm{K \alpha}$ radiation $(\mathrm{k}=1.5406 \mathrm{~A})$, operating at $40 \mathrm{kV}$ and $40 \mathrm{~mA}$. The crystallinity, $X_{\mathrm{c}}$ was calculated from the height ratio in the diffractogram using the Equation 1a (Juarez-de la Rosa et al., 2012).

$X_{c}(\%)=\left[I_{c} /\left(I_{c}+I_{a}\right)\right] \times 100$

Where $I_{c}$ is the maximum intensity of crystalline region and $I_{a}$ is the intensity of amorphous region of the sample. This was done for crystalline peaks present for each component and the average values were calculated (see Table 4). Crystalline size normal to hkl plane (Dhkl) was calculated from the full width at half height of the source curve using Equation 1b (Kaya et al., 2014).

$\mathrm{D}_{h k l}=\mathrm{k} \lambda / \beta \cos \theta$

Where $\mathrm{k}$ is a constant (indicative of crystallite perfection and is assumed to be 1 ); $\lambda(\AA)$ is the wave length of incident radiation (1.5406 $\AA$ ); $\beta$ (rad) is the width of the crystalline peak at half height and $\theta(\mathrm{deg})$ is the diffraction angle corresponding to the crystalline peak.

\subsection{Scanning Electron Microscopy (SEM)}

The samples micrographs were produced via a scanning electron microscopy model Phenom Eindhoven, Netherlands. It works with an electron intensity beam of $15 \mathrm{kV}$, while the samples to be observed were usually mounted on a conductive carbon imprint left by the adhesive tape. This is usually prepared by placing the samples on the circular holder and coated for 5 min to enable it conduct electricity. 


\section{RESULTS AND DISCUSSION}

\subsection{Setting time determination}

In Fig. 2, above 10 wt. \% AlDr of cement replacement, the mortar adhesive binding force decline as the paste became unstable with foams formed over the mould. In the control (ordinary Portland cement, OPC), the initial setting time was > 45minutes and the final time of setting was $\leq 375 \mathrm{mins}$. In Reddy and Neeraja (2016) aluminium dross was found to retards the initial setting while it accelerates the final setting of concrete. However, in this study both the initial and final setting time at $10 \mathrm{wt}$. \% AlDr replacement of cement were accelerated $(1 \mathrm{hr} 20 \mathrm{mins}$; $3 \mathrm{hrs}$ ) such that these were lower than the control ( $2 \mathrm{hrs} 48 \mathrm{mins}$; $4 \mathrm{hrs})$ as shown in Fig. 2. This may be attributed to the reaction of metallic aluminium in dross in the presence of moisture to form film of aluminium hydroxide, which has cementitious characteristics

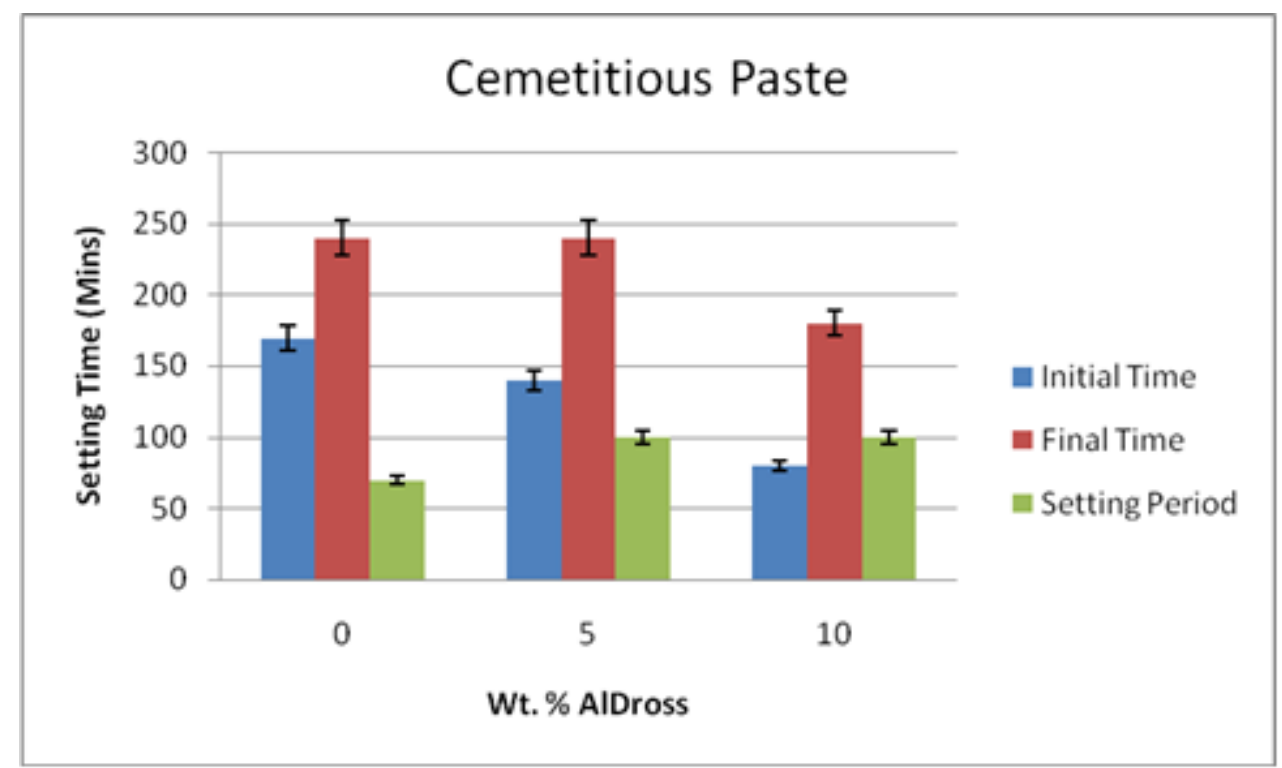

Fig. 2. Setting time Cement-Aluminum Dross Paste.

\subsection{Compressive strength of cured concrete cubes}

In Fig. 3, the compressive strengths of control concrete cubes progressed from 7 days $\left(\sim 7 \mathrm{~N} / \mathrm{mm}^{2}\right)$ to 42 days $\left(\sim 16.89 \mathrm{~N} / \mathrm{mm}^{2}\right)$ cured period except a slight decline at $28^{\text {th }}$-day $\left(\sim 13 \mathrm{~N} / \mathrm{mm}^{2}\right)$. The strengths of the concretes were weaker compared to the control at $5 \mathrm{wt} . \%$ AlDr replacement of cement for 7, 14, 21 and 42 days except at $28^{\text {th }}$-day curing $\left(\sim 15.5 \mathrm{~N} / \mathrm{mm}^{2}\right)$ where it is better than the control concrete cube $\left(\sim 13 \mathrm{~N} / \mathrm{mm}^{2}\right)$. The compressive strengths of cubes with partial replacement of cement with AlDr is only stronger than the control at $10 \mathrm{wt} . \%$ AlDr replacement of cement for all curing periods considered. The $42^{\text {th }}$-day cured cube $\left(\sim 16.96 \mathrm{~N} / \mathrm{mm}^{2}\right)$ showed slightly better strength than control $\left(\sim 16.89 \mathrm{~N} / \mathrm{mm}^{2}\right)$. Cement partial replacement by AlDr higher than $10 \mathrm{wt}$ \% produced cubes with strengths that decline and these 
are far weaker than the control concrete cubes. The reduction compressive strength to failure with aluminum dross replacement beyond $10 \mathrm{wt} . \%$ could be attributed to the occurrence of the reaction in Equation 2.

$\mathrm{Ca}(\mathrm{OH})_{2}+2 \mathrm{HCl} \Rightarrow \mathrm{CaCl}_{2}+2 \mathrm{H}_{2} \mathrm{O}$

The XRD patterns revealed that $\mathrm{Ca}(\mathrm{OH})_{2}$ concentration for the cementitious reaction declines in acidic environment as revealed by the low intensity shown by the calcite phase in Fig. $6 \mathrm{~g}$ (15 wt.\% AlDr) compared with that of Fig. $6 f(10 \mathrm{wt} \%$ AlDr). This causes decline in concrete strength with increment of AlDr in Lagoon environment.

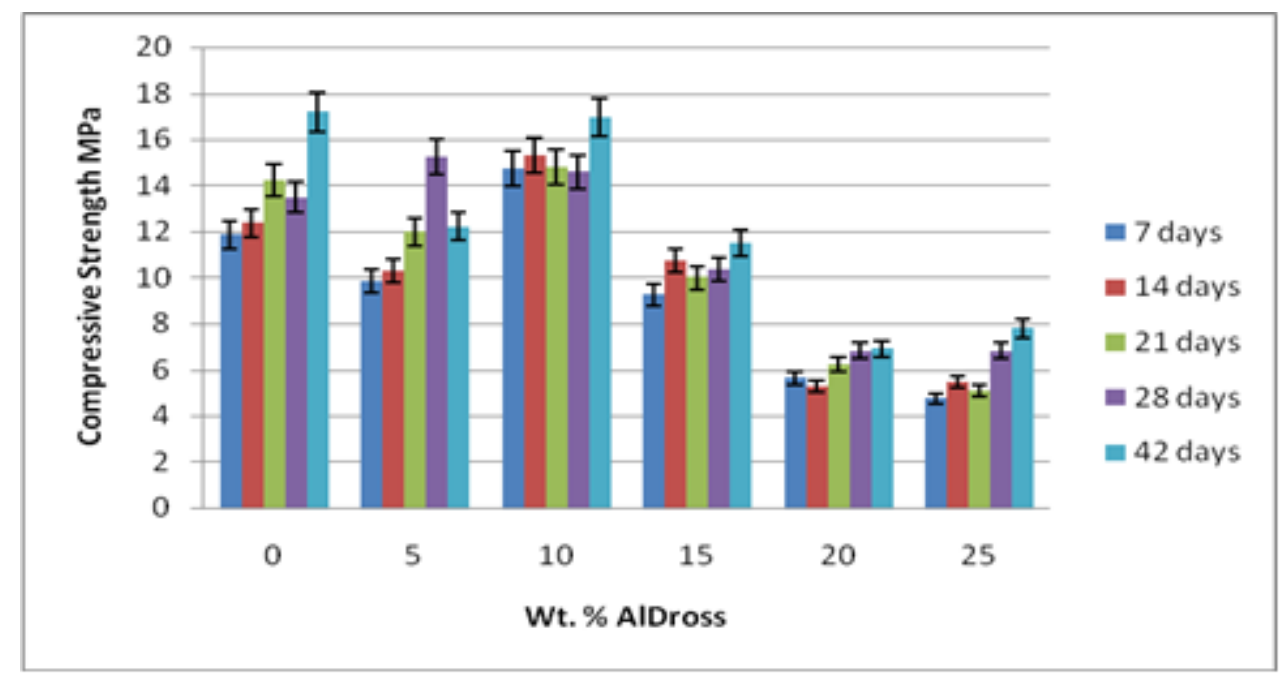

Fig. 3.Compressive Strengths of Lagoon Cured Concrete Cubes.

\subsection{Weight of cast concrete cubes before and after curing}

The study desired to known if the partial cement replacement with AlDr will cause significant additional weight to concrete. From Fig. 4, the weights of the tested concrete cubes before and after curing are shown. The weights of control cubes with period of curing are similar to those of 10 wt. \% AlDr replacement of cement. At 42- day cured period, the control weights are the same as that of $10 \mathrm{wt} . \%$ AlDr replacement of cement $(\sim 7.75 \mathrm{Kg})$. The cubes with AlDr replacement of cement showed an expansion with a concave surface at the open end similar to that observed by Reddy and Neeraja (2016). This is observed for higher replacement of cement by AlDr as well. The expansion is due to formation of more voids in the concrete and this is the mechanism responsible for cubes lightness at 20 and 25 wt.\% AlDr. Foaming occurred as expansion progresses with more entrapped air and this produced negative effect on strength (Reddy and Neeraja, 2016). 


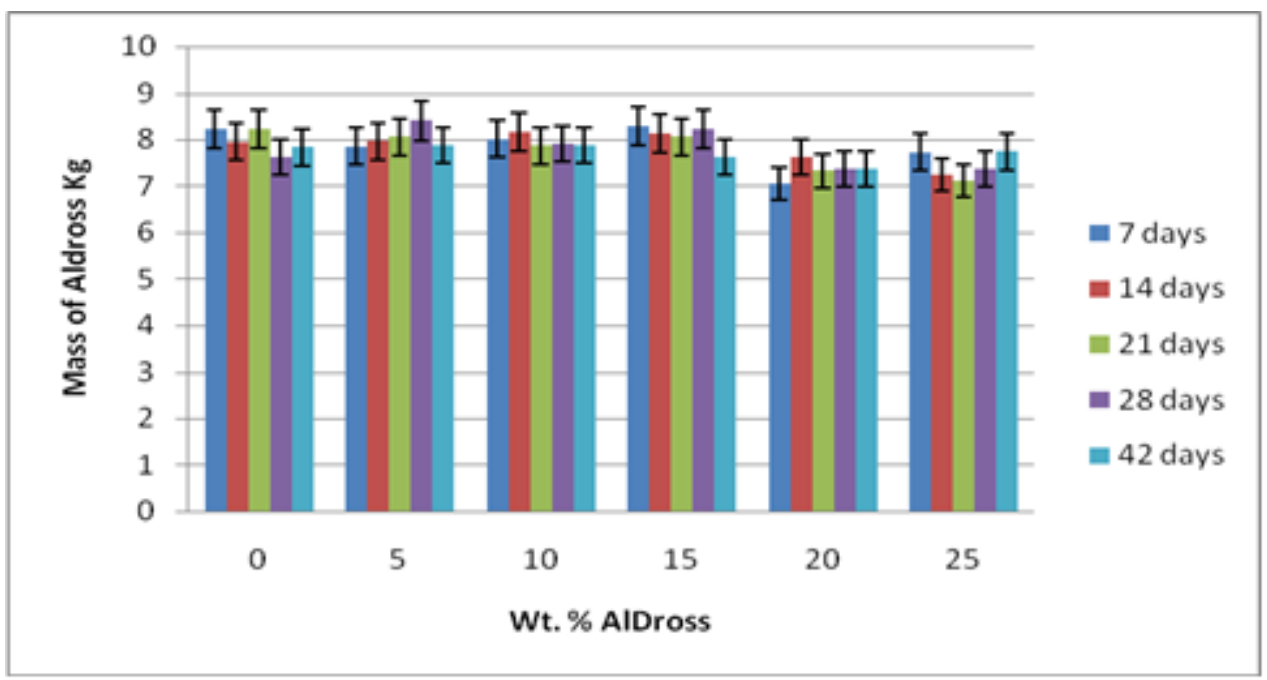

Fig. 4. Weight of cast Concrete Cubes with curing period.

Beyond 28-day of curing, the lagoon water salinity and chloride ion concentrations were seen to be well above the standard (Table 1). Chlorides are known to be responsible for corrosion initiation and the mechanism by which this occurs is not completely known. However, it is postulated that chloride ions penetrate the protective oxide film in the concrete matrix with ease than do other ions. The corrosion propensity increases as the chloride content of concrete increases PCA R\&D Serial No. 2617 (2002). The reductions in weight during curing in this environment is attributed to the chloride ion concentrations and its attendant effects on the concrete leading to loss of materials as reflected in weight reduction of concrete cubes.

\subsection{Compressive strength behaviours of cured reinforced aluminium dross concrete column}

The compressive strengths of cast columns cured in lagoon water from 1-6 months is shown in Fig. 5. The control concrete columns increase in strengths from $\sim 5-7 \mathrm{~N} / \mathrm{mm}^{2}$ as curing period extends from 1- 2 months and thereafter decline to $\sim 6 \mathrm{~N} / \mathrm{mm}^{2}$ at end of 6 months' period. The replacement of cement in the concrete columns with 5 wt.\% AlDr showed a different strength patterns with curing period. Although, the strengths are inferior to those of control columns, the strengths increased to a peak $\left(\sim 6 \mathrm{~N} / \mathrm{mm}^{2}\right)$ at 6 months cured period. It is observed in these columns that sudden strengths drop occurred between 1.5 and 2.5 months, which may be attributed to casting imperfections owing to entrapped air occasioned by the fast reactions of aluminum in the dross with oxygen recognized by the foaming actions at the column open ends during solidification. The solidification was observed to last about 48 hours before demoulding the cast column to allow for phase transformation from semi-solid to hardened concrete. The 10 wt.\% AlDr cement replacements in the cast column revealed strengths increment from $\sim 7 \mathrm{~N} / \mathrm{mm}^{2}$ to $\sim 9.5 \mathrm{~N} / \mathrm{mm}^{2}$ from 1 to 6 months curing period. However, there 
was drop in strength between 1-2 months traceable to the presence of AlDr as partial cement replacement. Because of the effect of Aldross in the chemical reaction process of the concrete. The strength pattern for 15 wt.\% AlDr cast column was not different from that observed with 10 wt. \% AlDr. Strength drop between 1 to 2 months and a rise there-after to peak value of $\sim 8$ $\mathrm{N} / \mathrm{mm}^{2}$ for 6 months cured column. The $20 \mathrm{wt}$ \% AlDr cast columns showed slight strength increment with period of curing with drops at 1.5 and 2.5 months cured period. The maximum strength $\left(\sim 4.25 \mathrm{~N} / \mathrm{mm}^{2}\right)$ obtained in this set of columns occurred at the end of 6 months cured period.

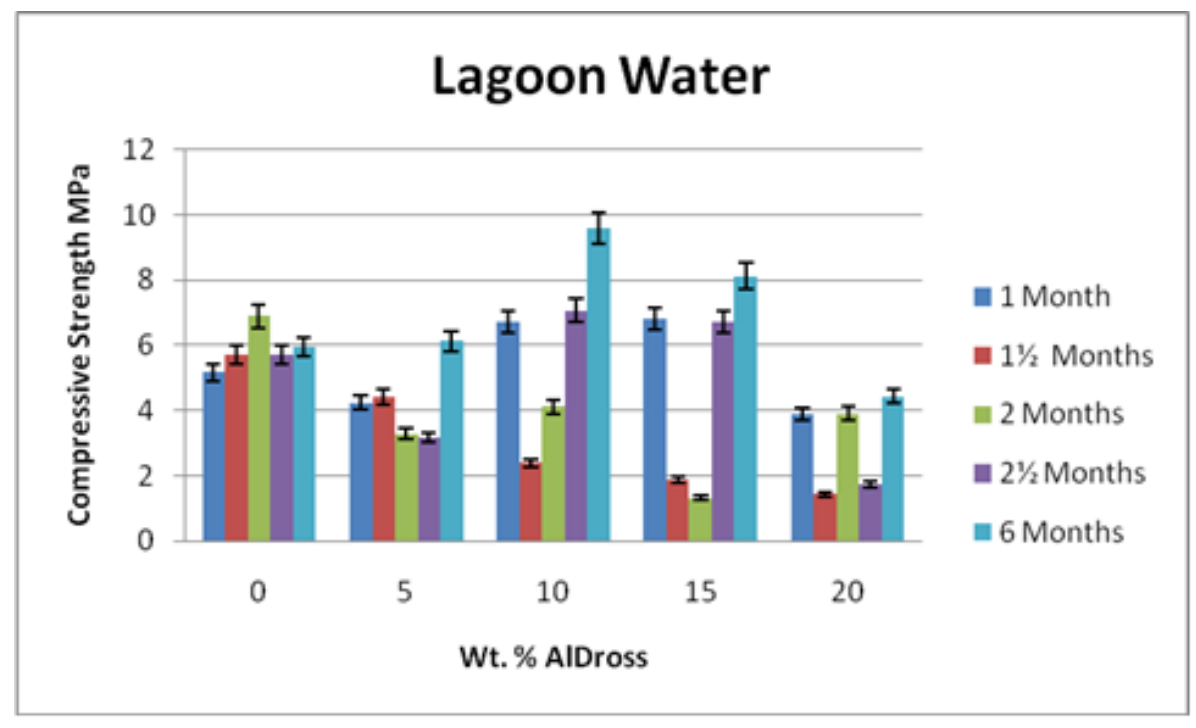

Fig. 5. Compressive Strength characteristics of Lagoon water-cured concrete columns columns with AIDr dross Pozzolan.

The strength $\left(\sim 9.5 \mathrm{~N} / \mathrm{mm}^{2}\right)$ obtained with 10 wt. \% AlDr cast column cured for 6 months in Lagoon water proved to be of importance as this was better than the control columns in the lagoon environment $\left(\sim 7 \mathrm{~N} / \mathrm{mm}^{2}\right)$ at 2-month.

\subsection{XRD description of concrete AIDr Cubes}

The XRD patterns shown from Fig.s 6a-6i are for cement, aluminum dross (AlDr), pure cement cube with fine aggregate, pure concrete cube (control), 5,10,15, 20 and 25 wt.\% AlDr cement concrete cubes. The pure concrete cube (control) contains prominent peaks of Calcite, Quartz, Rutile with Hexagonal and Tetragonal structures while Albite and Rutile has Anorthic(triclinic) and Tetragonal structures at $2 \theta=26.7$ and 27.9 respectively. For 5\% AlDr concrete cubes Calcite, Quartz (Hexagonal), Rutile (Tetragonal) structures are more prominent followed by Albite (Anorthic or triclinic), Rutile (Tetragonal) at 20=26.6 and 27.1 respectively. $10 \mathrm{wt} . \%$ AlDr concrete cubes contain peak of Calcite, Quartz, Rutile with Hexagonal, Tetragonal 
structures and Albite, Rutile with Anorthic(triclinic), Tetragonal structures at $2 \theta=26.5$ and 27.6 respectively. 15 wt.\% AlDr concrete cubes contain peak of Calcite, Quartz, Rutile with Hexagonal, Tetragonal structures and Albite, Rutile with Anorthic(triclinic), Tetragonal structures at $2 \theta=26.5$ and 27.4 respectively. $20 \mathrm{wt} . \%$ AlDr concrete cubes contain peak of Albite, Rutile with Anorthic(triclinic), Tetragonal structures and Quartz, Florite, Malite with Hexagonal structures at $2 \theta=26.6$ and 50 respectively. 25 wt. $\%$ AlDr concrete cubes contain peak of Calcite, quartz, Rutile with Hexagonal, Tetragonal structures and Portlandite, Oligoclass, Biotite with Hexagonal, Anorthic(triclinic), monoclinic structures at $2 \theta=26.7$ and 28 respectively.

Table 3 shows the crystal sizes and crystallinity of the concretes after curing. Control concrete (74.6-95.5\%) has higher crystallinity compared to cement (65.1-90.1\%) and AlDr (62.474.0\%). However, at $15 \mathrm{wt}$ \% AlDr cement concrete the crystallinity (78.1-96.2\%) is superior to others with variation in crystal sizes $(12.8-16.9 \AA)$ of the constituents of this concrete composite appear negligible when compared to others. Properties of cement concretes are affected not only by total porosity but also by the size distribution of the porosity. For 5 and 10 wt. \% AlDr-cement concretes the constituents have wide disparity in crystal sizes. This implies pores available for ingress of fluid into the concrete are little. Thus, there are few openings for chloride penetration into the concrete. The closer the crystal size of the concrete constituents are the more prone the concrete is to fluid ingress and therefore low hindrance to chloride damage in chloride laden water. The highest compressive strength at 10 wt.\% AlDr cement concrete is attributed to the crystal size range of the constituents that allows for closer particle interactions than others as affirmed by Siamak et al. (2020).

Table 3. Crystal parameters of Concrete-AIDr cubes with coarse aggregates.

\begin{tabular}{|c|c|c|c|c|c|c|c|c|}
\hline Parameters & Cement & $\mathrm{AlDr}$ & 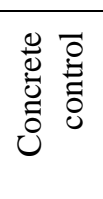 & 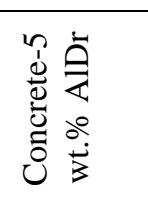 & 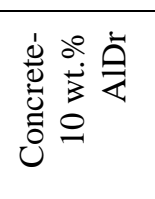 & 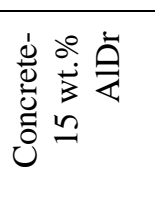 & 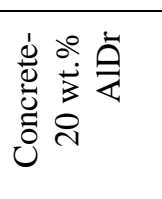 & 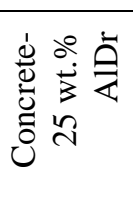 \\
\hline $\begin{array}{l}\text { Crystallinity } \\
\text { index (\%) }\end{array}$ & $\begin{array}{r}65.1- \\
90.1\end{array}$ & $\begin{array}{r}62.4- \\
74.0\end{array}$ & $\begin{array}{r}74.6 \\
- \\
95.5\end{array}$ & $\begin{array}{r}77.6- \\
96.9\end{array}$ & $76-92$ & $\begin{array}{l}78.1- \\
96.2\end{array}$ & $\begin{array}{r}72.8- \\
94.1\end{array}$ & $\begin{array}{r}72.2- \\
96.5\end{array}$ \\
\hline $\begin{array}{r}\text { Crystal size } \\
(\AA)\end{array}$ & $\begin{array}{r}7.3- \\
20.4\end{array}$ & $\begin{array}{r}9.5- \\
20.9\end{array}$ & $\begin{array}{l}9.5- \\
15.0\end{array}$ & 2.0-21.1 & $2.0-16.9$ & $\begin{array}{r}12.8- \\
16.9\end{array}$ & $\begin{array}{r}13.0- \\
25.6\end{array}$ & $\begin{array}{r}15.2- \\
21.5\end{array}$ \\
\hline
\end{tabular}




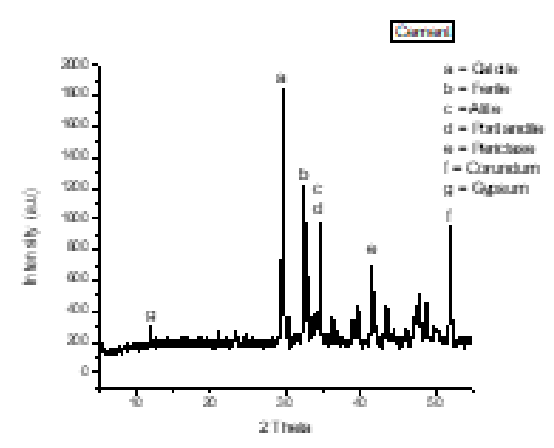

Fig. 6a. Pure cement diffractogram

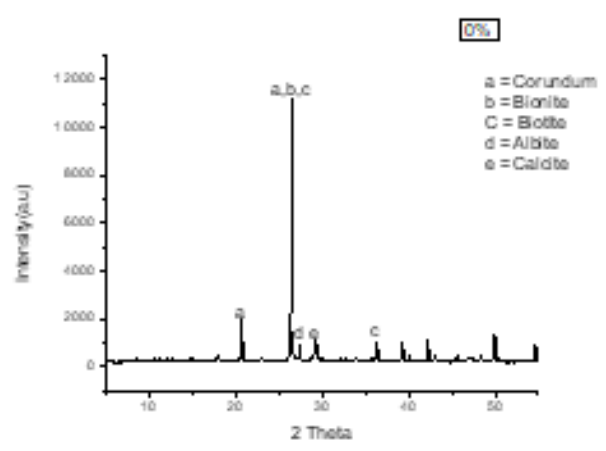

Fig. 6c. Pure cement cube with fine aggregate diffractogram

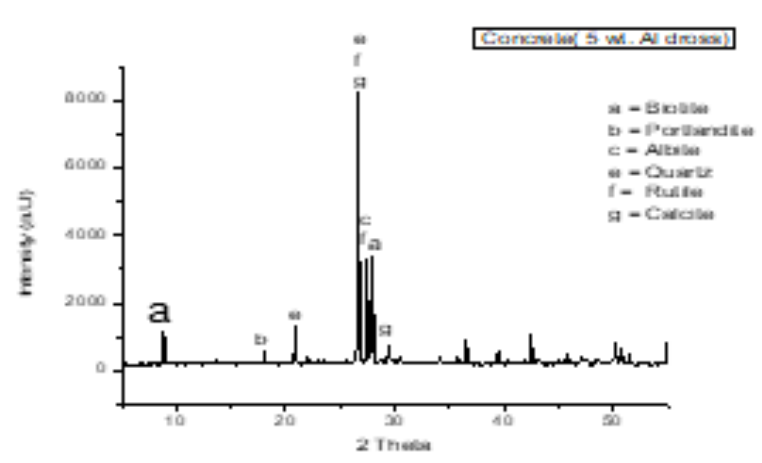

Fig. 6e. Concrete 5 wt. \% cube with coarse aggregate diffractogram

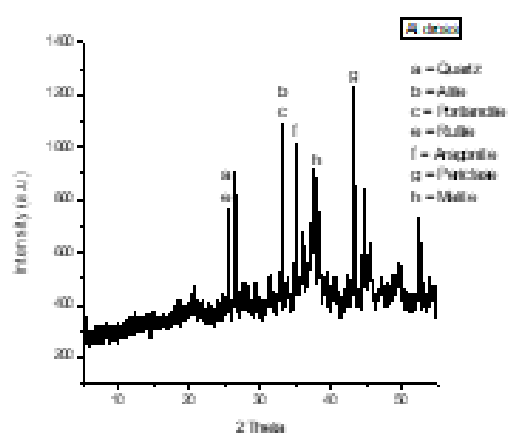

Fig. 6b. Secondary Aluminium dross diffractogram

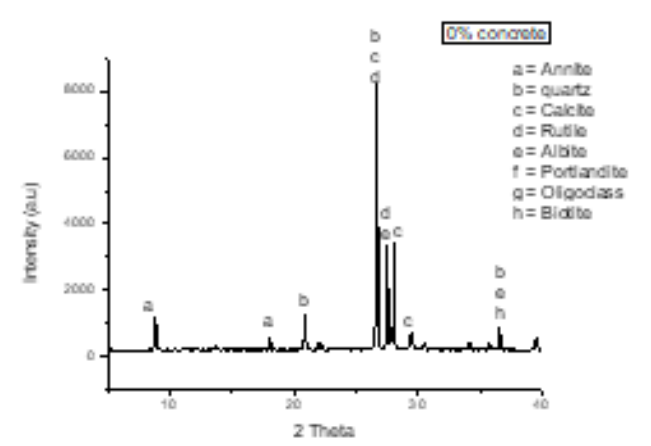

Fig. 6d. Pure Concrete with coarse aggregate diffractogram

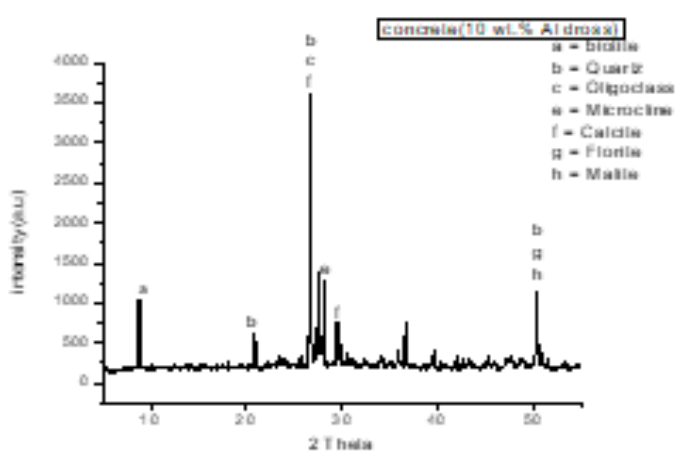

Fig. 6f. Concrete 10 wt.\% cube with coarse aggregate diffractogram 


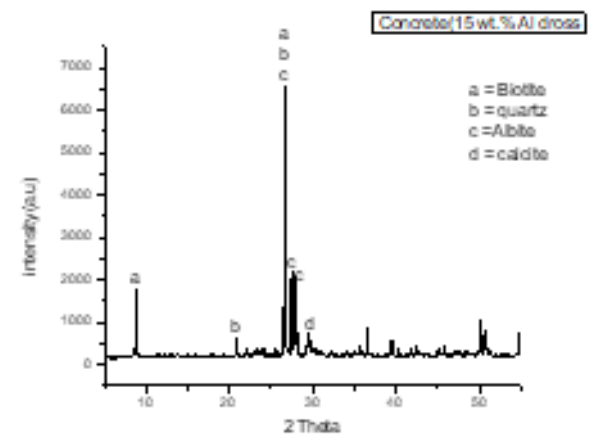

Fig. 6g. Concrete 15 wt.\% AIDr cube with coarse aggregate diffractogram

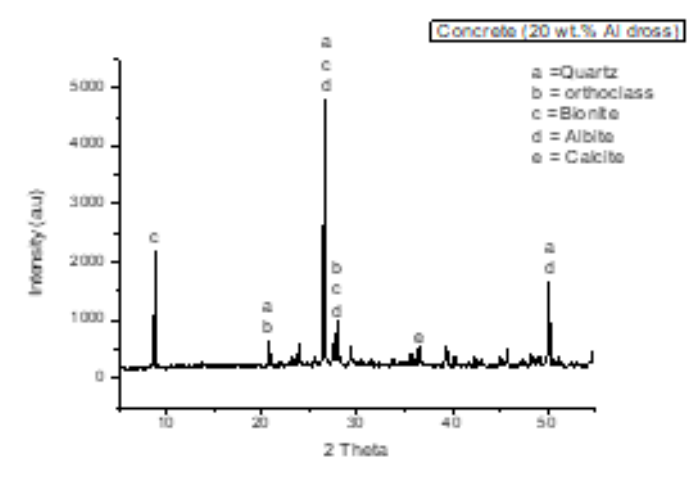

Fig. 6h. Concrete 20 wt.\% AIDr cube with coarse aggregate diffractogram

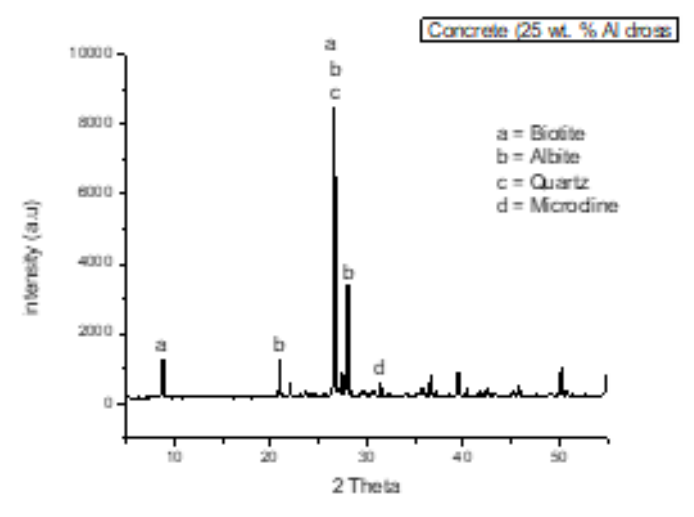

Fig. 6i. Concrete 25 wt.\% AIDr cube with coarse aggregate diffractogram

\subsection{Scanning Electron Morphological Analysis of Concrete- AlDr cubes with coarse aggregate}

The elemental composition of aluminum dross and cement are shown in Tables 4 and 5 respectively. The SEM result of AIDr, revealed that the main constituent is Corundum and some quantity of iron. This was also further confirmed by EDX result. The microstructure has irregular shape, no void or cavity. The image indicates that the particles are well dispersed. Pure cement cube, showed calcite (light gray) and quartz (dark gray) as the main constituent of cement. The surface is relatively smooth with particle like dispersion on the surface with little Cavity. At the various weight $\%$ AlDr, Corundum was scattered all around the surface. The surface roughness increased as the AlDr is increased in the concrete and in the fine aggregate. Presence of cavity (void) was observed as the AlDr in the matrix increase to $25 \mathrm{wt} . \%$. 


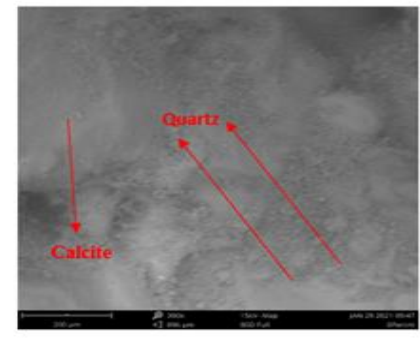

Plate 1: Pure cement cube with fine aggregate morphology

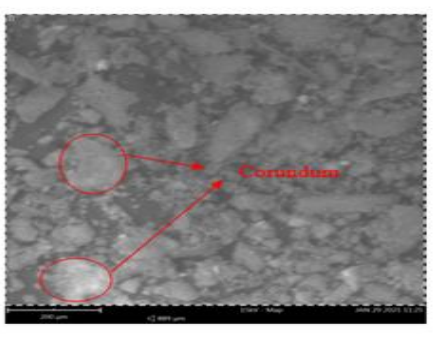

P1ate 2: A1 dross morphology

Plate 1. Pure cement cube with fine aggregate morphology Plate 2: AlDr morphology.

Table 4. Elemental composition of aluminum dross via EDX.

\begin{tabular}{rrrrrrrrrrrrrrrrr}
\hline Element & $\mathrm{Al}$ & $\mathrm{Fe}$ & $\mathrm{Si}$ & $\mathrm{Cl}$ & $\mathrm{Ca}$ & $\mathrm{K}$ & $\mathrm{Ti}$ & $\mathrm{Nb}$ & $\mathrm{Ag}$ & $\mathrm{Na}$ & $\mathrm{S}$ & $\mathrm{Y}$ & $\mathrm{Mg}$ & $\mathrm{V}$ & $\mathrm{Mn}$ & $\mathrm{P}$ \\
\hline $\mathrm{Wt} \%$ & 47.72 & 10.8 & 10.36 & 7.35 & 6.32 & 2.96 & 2.88 & 2.39 & 2.0 & 1.55 & 1.5 & 1.42 & 1.17 & 0.66 & 0.53 & 0.38 \\
\hline
\end{tabular}

Table 5. Elemental composition of cement via EDX.

\begin{tabular}{rrrrrrrrrrrrrr}
\hline Element & $\mathrm{Ca}$ & $\mathrm{Si}$ & $\mathrm{Fe}$ & $\mathrm{Mg}$ & $\mathrm{Al}$ & $\mathrm{Cl}$ & $\mathrm{Ag}$ & $\mathrm{K}$ & $\mathrm{S}$ & $\mathrm{Y}$ & $\mathrm{Nb}$ & $\mathrm{Na}$ & $\mathrm{P}$ \\
\hline $\mathrm{Wt} \%$ & 53.16 & 24.57 & 3.90 & 3.03 & 2.90 & 2.21 & 2.00 & 1.94 & 1.82 & 1.76 & 1.72 & 0.56 & 0.42
\end{tabular}

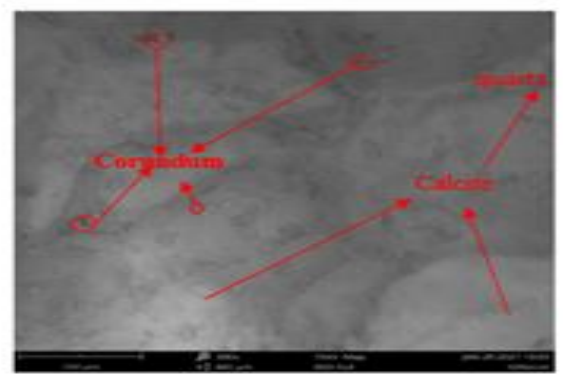

Plate 3 : Cement- 10 wt. $\%$ Al dross cube morphology

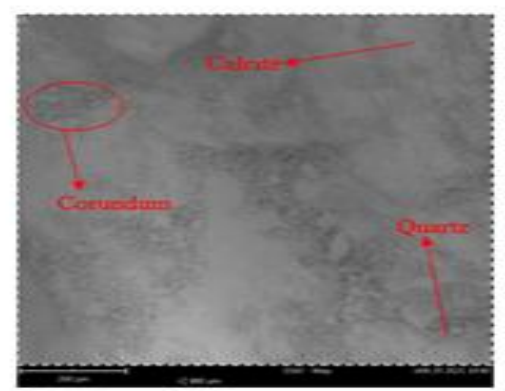

Plate 5: Cement- 20 wt. $\%$ Al dross cube morphology

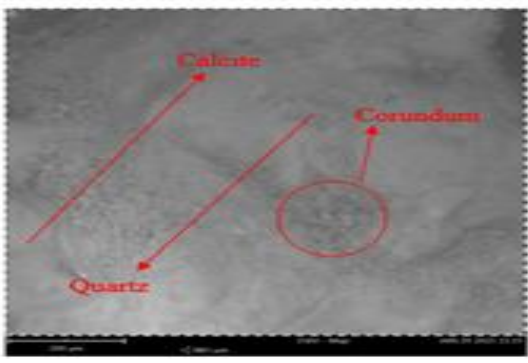

Plate 4: Cement- 15 wt. $\%$ Al dross cube morphology

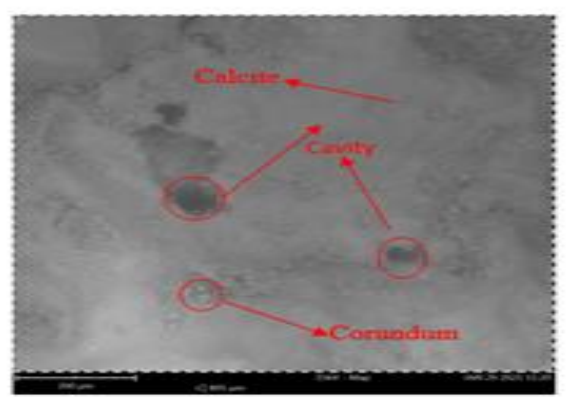

Plate 6: Cement- 25wt. \% Al dross cube morphology 


\section{CONCLUSION}

In this study the compressive strength to failure tests were conducted on concrete cubes with partial cement replacement by AlDr and cured in lagoon water at 7, 14, 21, 28 and 42 days. The 10 wt.\% AlDr replacement gave a satisfactory result of $14.59 \mathrm{~N} / \mathrm{mm}^{2}$ at 28 -day, and $16.96 \mathrm{~N} / \mathrm{mm}^{2}$ at 42 - day. Comparing other previous studies with this present one, it is deduced that extent of cement replacement by AlDr would depend on the amount of $\mathrm{Al}_{2} \mathrm{O}_{3}, \mathrm{SiO}_{2}, \mathrm{Al}-$ metal present in the dross. Highly rich alumina dross will allow for higher cement replacement than what has been observed in this work.

\section{REFERENCES}

Abbas, Y. de Graaf, D. B Olthuis, W. van den Berg, A (2014). No more conventional reference electrode: Transition time for determining chloride ion concentration," Analytica chimica acta vol. 821, 81-88.

Andrew R M (2018). Gobal CO2 emissions from cement production. Earth Syst. Sci. Data, Vol 10, Pp 195-217.

Juarez-de la Rosa, B.A., Quintana, P., Ardission, P.I., Yanez-Limon, J.M., and Alvarado-Gil, J.J. (2012). Effects of thermal treatments on structure of two black coral species chitinous exoskeleton. Journal of Material Sciences, Vol.47, pp. 990-998.

Kaya, M. Seyyar, O. Baran, T. Turkes, T. (2014). Bat guano as new and attractive chitin and chitosan source. Front. Zool.;11(1):1-10

Neville A (1995), Chloride attack of Reinforced Concrete - an overview. Materials and Structures, Vol 28, Pp 63-70.

Nilam Y. Galat, G. D. Dhawale and M. S. Kitey (2017). Performance of Concrete using Aluminum Dross. Journal of Emerging Technologies and Innovative Research (JETIR), Vol 4(7), Pg 1-10.

PCA R\&D Serial No. 2617 (2002). Types and causes of Concrete Deterioration. 1-16 Portland Cement Association All rights reserved.

Reddy, M. S and Neeraja, D. (2016). Mechanical and durability aspects of concrete incorporating secondary aluminium slag. Resource-Efficient Technologies 2. 225-232. 
Siamak ImanianGhazanlou, Maisam Jalaly, Sadegh Sadeghzadeh and Asghar Habibnejad Korayem (2020). A comparative study on the mechanical, physical and morphological properties of cement-micro/nanoFe3O4 composite. Scientific Reports 10:2859

Valipour M (2014). Drainage, Waterlogging and Salinity. Archives of Agronomy and Soil Sciences, Vol 60(12) Pp 1625-164. 